\title{
Korelasi antara penggunaan media video dan motivasi belajar dengan prestasi belajar pendidikan Pancasila dan kewarganegaraan peserta didik
}

\author{
Verawati Ningrum, ${ }^{a, 1}$ Supriyadi ${ }^{b, 2}$ \\ a,b Program studi PPKn, Universitas Ahmad Dahlan, Yogyakarta \\ ${ }^{1}$ verawati1500009033@webmail.uad.ac.id² supriyadi@ppkn.uad.ac.id \\ * korespondensi penulis
}

\begin{abstract}
ABSTRAK
Penelitian ini dilatarbelakangi oleh minimnya penggunaan media pada proses pembelajaran Pendidikan Pancasila dan Kewarganegaraan. Penelitian ini bertujuan untuk mengetahui ada tidaknya korelasi antara penggunaan media video dan motivasi belajar dengan prestasi belajar Pendidikan Pancasila dan Kewarganegaraan peserta didik kelas VIII SMP Muhammadiyah Pakem. Jenis penelitian ini adalah dengan pendekatan kuantitatif. Populasi yang digunakan dalam penelitian ini adalah peserta didik kelas VIII yang berjumlah 149. Teknik pengumpulan data yang digunakan dengan menggunakan angket, tes, dan observasi. Teknik analisis data yang digunakan untuk menguji hipotesis adalah teknik korelasi product moment. Hasil penelitian ini menunjukkan bahwa berdasarkan nilai $r$ hitung (Pearson correlations) nilai $\mathrm{r}$ hitung antara X1 dengan $\mathrm{Y}$ adalah $0,048<\mathrm{r}$ tabel 0,361 , tidak ada korelasi antara variabel (X1) dengan (Y). Selanjutnya, diketahui nilai $\mathrm{r}$ hitung antara motivasi belajar (X2) dengan pretasi belajar (Y) adalah sebesar $0,114<$ 0,361, tidak ada korelasi antara variabel (X2) dengan (Y). Besarnya korelasi adalah 0,136, maka Ha ditolak dan Ho diterima, artinya tidak ada korelasi antara penggunaan media video dan motivasi belajar dengan prestasi belajar Pendidikan Pancasila dan Kewarganegaraan peserta didik kelas VIII tahun ajaran 2018/2019 SMP Muhammadiyah Pakem.
\end{abstract}

Kata kunci: media pembelajaran, video pembelajaran, motivasi belajar, prestasi belajar, ppkn

\begin{abstract}
This research is motivated by the lack of use of media in the learning process of Pancasila and Citizenship Education. This study aims to determine whether there is a correlation between the use of video media and learning motivation with learning achievement of Pancasila Education and Citizenship of VIII grade students of Muhammadiyah Middle School Pakem. This type of research is a quantitative approach. The population used in this study were students of class VIII, amounting to 149. Data collection techniques used were using questionnaires, tests, and observations. The data analysis technique used to test the hypothesis is the product moment correlation technique. The results of this study indicate that based on the value of $r$ arithmetic (Pearson correlations) the calculated $r$ value between $X 1$ and $Y$ is $0.048<r$ table 0.361, there is no correlation between variables $(X 1)$ with $(Y)$. Furthermore, it is known that the value of $r$ arithmetic between learning motivation $(X 2)$ and learning achievement $(Y)$ is $0.114<0.361$, there is no correlation between variables (X2) and (Y). The magnitude of the correlation is 0.136 , then Ha is rejected and Ho is accepted, meaning that there is no correlation between the use of video media and learning motivation with the learning achievement of Pancasila Education and Citizenship of Class VIII students in the 2018/2019 school year Muhammadiyah Pakem Middle School.
\end{abstract}

Keywords: use of video media, learning motivation, learning achievement

Copyright $(2020$ Universitas Ahmad Dahlan

\section{PENDAHULUAN}

Media pembelajaran merupakan salah satu faktor pendukung dalam suatu pembelajaran. Penggunaan media dalam proses pembelajaran akan lebih menarik perhatian peserta didik untuk menumbuhkan motivasi belajar, serta materi akan lebih mudah dipahami maknanya sehingga peserta didik dapat memahami materi yang disampaikan oleh guru. Penelitian oleh Putri di MTsN Plupuh Sragen menyebutkan bahwa terdapat pengaruh penggunaan media pembelajaran terhadap motivasi belajar peserta didik. Hasil penelitian tersebut menginformasikan terdapat pengaruh signifikan antara media pembelajaran terhadap motivasi belajar peserta didik (Putri, 2017:14). Hal ini menunjukkan bahwa jika dalam suatu pembelajaran guru menggunakan media pembelajaran yang tepat berupa pemilihan media maka proses pembelajaran pun dapat memotivasi peserta didik. Pada kenyataannya guru menyampaikan bahan pengajaran hanya menggunakan bahasa lisan atau tanpa disertai alat pendukung (Gustina, 2010:17). Peran guru sangat penting dalam pembelajaran, guru diharapkan mampu memilih media pembelajaran yang tepat dan sesuai dengan materi yang akan disampaikan. 
Prestasi belajar yang rendah disebabkan oleh banyak faktor salah satunya adalah motivasi belajar. Oleh karena itu, guru sangat berperan penting dalam meningkatkan minat belajar peserta didik. Berdasarkan penelitian yang dilakukan oleh Ismiyati di SMP Negeri 2 Gedangsari Gunung Kidul Tahun ajaran 2015 bahwa dari hasil pengamatannya di sekolah tersebut, khususnya peserta didik kelas VIII A hasil proses belajar mengajar menunjukkan bahwa peserta didik kurang memperhatikan, ramai sendiri pada saat peserta didik menerima pelajaran PPKn. Dari penelitian tersebut maka dapat diketahui bahwa motivasi belajar sangatlah penting dalam meningkatkan prestasi belajar peserta didik (Ismiyati, 2015:39-56).

Berdasarkan permasalahan yang ada, maka perlu adanya media yang sesuai dengan karakteristik peserta didik untuk mata pelajaran Pendidikan Pancasila dan Kewarganegaraan. Media video merupakan salah satu media yang dapat digunakan dalam pembelajaran mata pelajaran Pendidikan Pancasila dan Kewarganegaraan. Dengan pembelajaran menggunakan media video, peserta didik dapat termotivasi untuk mengikuti pembelajaran Pendidikan Pancasila dan Kewarganegaraan. Adanya penggunaan media video menjadikan peserta didik memiliki motivasi dalam belajar, sehingga diharapkan prestasi belajar peserta didik akan meningkat dengan penggunaan media video tersebut. Tujuan penelitian ini adalah untuk mengetahui ada tidaknya korelasi antara penggunaan media video dan motivasi belajar dengan prestasi belajar Pendidikan Pancasila dan Kewarganegaraan peserta didik kelas VIII SMP Muhammadiyah Pakem.

\section{METODE}

Jenis penelitian yang digunakan merupakan jenis penelitian kuantitatif yang bertujuan untuk mengetahui ada tidaknya korelasi antara penggunaan media video dan motivasi belajar dengan prestasi belajar Pendidikan Pancasila dan Kewarganegaraan peserta didik. Populasi penelitian ini sejumlah 149 siswa dan sampel 30 siswa. Teknik pengumpulan data berupa angket, tes dan observasi. Teknik analisis data dalam penelitian kuantitatif menggunakan statistik, dalam penelitian ini menggunakan korelasi. Penggunaan media video ini dapat digunakan dalam proses pembelajaran apabila terdapat hubungan antara penggunaan media video dan motivasi belajar dengan prestasi belajar Pendidikan Pancasila dan Kewarganegaraan peserta didik.

Penelitian ini menggunakan teori motivasi menurut Herzberg (Majid, 2013:315) dimana ada dua faktor yang mendorong seseorang untuk mencapai kepuasan yaitu faktor ekstrinsik (bersumber dari luar diri seseorang) dan faktor ekstrinsik (bersumber dari diri seseorang). Dengan tahapan pembelajaran menggunakan media video dalam materi Memahami Kedudukan dan Fungsi Pancasila, kemudian pengisian angket penggunaan media video, angket motivasi belajar dan tes prestasi belajar.

\section{HASIL DAN PEMBAHASAN}

Berdasarkan nilai $\mathrm{r}$ hitung (Pearson Correlations)

Tabel 1. Ringkasan Hasil Koefisien Korelasi Product Moment

\begin{tabular}{|c|c|c|c|c|}
\hline & & Prestasi Belajar & Video & Motivasi \\
\hline \multirow{3}{*}{ Pearson Correlation } & \multicolumn{2}{|c|}{ Prestasi Belajar 1,000} &, 048 &,- 114 \\
\hline & Video &, 048 & 1,000 & 217 \\
\hline & Motivasi &,- 114 & 217 & 1,000 \\
\hline \multirow{3}{*}{ Sig. (1-tailed) } & Prestasi Belajar & & 400 &, 274 \\
\hline & Video &, 400 & &, 125 \\
\hline & Motivasi &, 274 &, 125 & \\
\hline \multirow{3}{*}{$\mathrm{N}$} & Prestasi Belajar & 30 & 30 & 30 \\
\hline & Video & 30 & 30 & 30 \\
\hline & Motivasi & 30 & 30 & 30 \\
\hline
\end{tabular}

Diketahui nilai $\mathrm{r}$ hitung antara $\mathrm{X} 1$ dengan $\mathrm{Y}$ adalah $0,048<\mathrm{r}$ tabel 0,361 , maka dapat disimpulkan bahwa tidak ada korelasi antara variabel penggunaan media video dengan variabel prestasi belajar. Selanjutnya, diketahui nilai $r$ hitung untuk hubungan motivasi belajar (X2) dengan prestasi belajar $(\mathrm{Y})$ adalah sebesar $0,114<$ 0,361 , maka dapat disimpulkan tidak ada korelasi antara motivasi belajar dengan prestasi belajar. Dalam penelitian ini besarnya korelasi adalah 0,136 , maka dapat disimpulkan bahwa Ha ditolak dan Ho diterima, yaitu tidak ada korelasi antara 
penggunaan media video dan motivasi belajar dengan prestasi belajar.

Korelasi bertujuan untuk mengetahui ada tidaknya hubungan antar variabel. Penggunaan media video dan motivasi belajar dengan prestasi belajar Pendidikan Pancasila dan Kewarganegaraan peserta didik pada materi Kedudukan dan Fungsi Pancasila ini tidak dapat diterapkan dalam proses pembelajaran. Penggunaan media video dalam materi Kedudukan dan Fungsi pancasila tidak berhubungan dengan motivasi dan prestasi belajar peserta didik, sehingga perlu adanya penggunaan media lain dalam materi tersebut.

\section{KESIMPULAN}

Berdasarkan hasil yang telah diperoleh dari penggunaan media video dan motivasi belajar dengan prestasi belajar Pendidikan Pancasila dan Kewarganegaraan peserta didik, besarnya korelasi adalah 0,136, maka dapat disimpulkan bahwa $\mathrm{Ha}$ ditolak dan Ho diterima, yaitu tidak ada korelasi antara penggunaan media video pada materi Memahami Kedudukan dan Fungsi Pancasila dan motivasi belajar dengan prestasi belajar Pendidikan Pancasila dan Kewarganegaraan peserta didik kelas VIII Tahun ajaran 2018/2019 SMP Muhammadiyah Pakem.

\section{UCAPAN TERIMA KASIH}

Penulis mengucapkan terima kasih kepada pihak-pihak yang telah membantu peneliti untuk menyelesaikan skripsi ini. Ucapan terima kasih ini saya ucapkan kepada seluruh civitas akademik Universitas Ahmad Dahlan, dan pihak SMP Muhammadiyah Pakem.

\section{DAFTAR PUSTAKA}

Gustina. (2010). Pengaruh Penggunaan Media Pembelajaran Berbasis Macromedia Flash 8 Terhadap Motivasi dan Hasil Belajar Kognitif Siswa kelas VII SMPN 18 Makasar Studi pada Materi Pokok Asam, Basa dan Garam. Universitas Khairun.

Ismiyati. (2015). Peningkatan Prestasi dan Motivasi Belajar PPKn Siswa Kelas VIII A SMP Negeri 2 Gedangsari Gunung Kidul Melalui Pembelajaran Group Investigation. Universitas Kristen Satya Wacana.

Majid, A. (2013). Strategi Pembelajaran. Bandung: PT Remaja Rosdakarya Offset.

Putri, Wakhidati, N. (2017). Pengaruh Media Pembelajaran Terhadap Motivasi Belajar
Bahasa Arab Siswa Madrasah Tsanawiyah. IAIN Salatiga

Sugiyono. (2014). Metode Penelitian Pendidikan

Pendekatan Kuantitatif, Kualitatif, dan R\&D. Bandung: Alfabeta. 